\title{
The Effect of Product Quality on Purchasing Decisions of Honda Motorized Vehicles with Matic Scooter Types
}

\author{
Putri Nilam Kencana \\ Universitas Pamulang \\ E-mail: putrinilamkencana@gmail.com
}

(Received: December-2017; Reviewed: January-2018; Accepted: February-2018;

Avalaibel Online: February-2018; Published: March-2018)

This is an open access article distributed under the Creative Commons Attribution License

CC-BY-NC-4.0 C2018 by author (https://creativecommons.org/licenses/by-nc/4.0/)

\begin{abstract}
The need for transportation nowadays becomes very important, compared to public transportation. The purpose of this study was to determine the effect of product quality on purchasing decisions of Honda motorized automatic scooters in Fatmawati, South Jakarta. The research method uses quantitative with a population of 680 , determination of the sample using the Slovin formula with an error rate of $10 \%$ obtained 87 respondents. Statistical tests use simple linear regression equations, correlation coefficient tests, determination coefficient tests, and significance tests. The results of the study there is a strong and significant positive effect between Product Quality on Purchasing Decisions with a regression value of 0.620 . The correlation coefficient ( $r$ ) of 0.604 and the value of determination (Kd) of 0.364 or $36.4 \%$ while the remaining $63.6 \%$ is influenced by other factors. Hypothesis testing using statistical tests $\mathrm{t}$ arithmetic obtained $\mathrm{t}$ arithmetic $>\mathrm{t}$ table (6.980> 1.9883), this is also strengthened with a significance value of $0,000<0.05$, it can be said to be significant. Thus H0 is rejected and H1 is accepted, meaning there is a positive and significant influence between Product Quality on Purchasing Decisions.
\end{abstract}

Keywords: Product quality; purchasing decisions; automatic motorcycles

\section{INTRODUCTION}

In facing a free market that is characterized by dynamic and competitive business development, companies must carry out marketing activities that are on target and change orientation towards how to serve their customers, handle competitors, and issue products (Nurbaity L, 2004; Peter \& Olson, 2014; Wibowo, Arifin, \& Sunarti, 2015). With the increasingly fierce competition, marketing activities carried out by the company must be increasingly enhanced and more directed so that it is right on target as well as service to consumers must be prioritized because at this time most consumers are more selective about what they receive and expect from a product.

The life of modern society now influences people's behavior patterns in purchasing (Istiatin, 2015; Kurniawati \& Arifin, 2015; Munadi, Ekonomi, \& Gunadarma, 2008). Modern 
life is often identified with a lifestyle that always follows the trends or developments of the era. The rapid development of technology along with the increase in human civilization has caused increasingly fierce competition. With the competition pushing every company to create excellence. Requirements that must be fulfilled by a company in order to be successful in the competition are trying to achieve the goal of creating and maintaining customers (Aryani \& Rosinta, 2010; Tjahjaningsih, 2016).

The need for transportation nowadays becomes very important, compared to public transportation, most people prefer to use private transportation, especially motorbikes to support their daily activities (Amalia, 2015; Haromain, 2016; Kurniasih, 2012). Aside from being a practical and agile transportation tool that can be used to get through traffic, motorcycle fuel consumption is cheaper compared to four-wheeled vehicles or using public transportation (Tahir, 2005; Widhiastuti, Priyadi, \& Akhmadali, 2013). Asosiasi Industri Sepeda Motor Indonesia (AISI) classifying the types of motorcycles as follows, motorcycle, automatic motorbike, and motorsport. A motorcycle is a motor that is intended for consumers in general whose segments can be generally accepted, with a simple form and can be used by anyone.

Automatic motorbike is a motor that is shown to consumers who want the practicality of driving in big cities which was originally made for women to be able to drive easily (Fatmawati \& Soliha, 2017; Nuriyanti, 2017; Pahlevi \& Sutopo, 2017; Zainuddin, 2018). Motorsport is a motor that is designated for men and young people who are no longer only made as a necessity to support mobility, although it is actually not practical in use as in a duck or automatic motorbike this is to meet the driving lifestyle. Consumers with high involvement product buying processes are consumers who when buying a product pay close attention to every feature in the product and the purchase process usually takes a long time. (Loindong \& Soegoto, 2014; Peter \& Olson, 2014; Schiffman \& Kanuk, 2008; Sumarwan, 2014)

Honda's market share has decreased from 2013 to 2014 and Honda's market share is predicted to decline in 2015, although it still ranks first or market leader, Yamaha as its eternal rival Honda experiences an increase every year while other brands also experience an increase amounted to $0.26 \%(19,865)$ motor units. The aspect that must be owned and maintained is a brand image because basically, a brand is an identity tool that specifically makes a promising value for both producers and consumers (Fristiana, 2012; Hidayati, Suharyono, \& Fanani, 2013; Soegoto, Mandey, \& Sari, 2014). A brand is not just a symbol used to identify a product or company. The role or function of a brand is not only as a differentiator from the products produced by one producer with another producer, but the brand is a determinant in producing a competitive advantage, namely competitive advantage, consumers perceive the brand as an added value for a product. A positive brand image will make consumers like a product with the relevant brand in the future, while for producers a good brand image will hinder competitors' marketing activities (Anastasia, U \& Yulia, 2014; Eriza, 2017; Isnaini Nur, Susanto, 2017; Suryonaningsih, 2016).

\section{METHOD}

The nature of this research is descriptive quantitative research on data collected and expressed in the form of numbers, although also in the form of quantitative data as a support, such as words or sentences arranged in a questionnaire, sentence of consultation or interview between researchers and informants. The population in this study is Honda customers who make regular purchases at Honda totaling 680 consumers. The technique used in sampling using 
accidental sampling (Convenience Sampling) is the selection of samples that are not planned or by chance. In this form, researchers draw population members to be sampled based on their ease of being found or the availability of population members only. To make time effective, after the questionnaire was filled in by the customer immediately returned the number of samples taken in the study. Data collection methods using primary data and secondary data. The instrument test uses the validity and reliability test, while the statistical test uses a simple regression equation, the correlation coefficient test, the coefficient of determination test and the significance test.

\section{RESULT AND DISCUSSION}

The automatic motorcycle still controls the market share of motorcycle sales in Indonesia in 2015 according to data AISI. This year, sales of 5 automatic motorcycles can reach $66 \%$ to $70 \%$, from motorcycle sales data of 7,236,000 million units, in which motorized scooters contributed 4,553,178 units or contributed $63.07 \%$ while the type of motorsport contributed $1,008,726$ units and motorcycle duck 1,656,702 units.

\section{Analisis Regresi Linear Sederhana}

Table 1

Results of Simple Linear Regression Data Processing

\section{Coefficients $^{a}$}

\begin{tabular}{|c|c|c|c|c|c|c|}
\hline \multirow{2}{*}{\multicolumn{2}{|c|}{ Model }} & \multicolumn{2}{|c|}{$\begin{array}{c}\text { Unstandardized } \\
\text { Coefficients }\end{array}$} & $\begin{array}{c}\text { Standardized } \\
\text { Coefficients }\end{array}$ & \multirow[b]{2}{*}{$T$} & \multirow[b]{2}{*}{ Sig. } \\
\hline & & $B$ & $\begin{array}{l}\text { Std. } \\
\text { Error }\end{array}$ & Beta & & \\
\hline \multirow[t]{2}{*}{1} & (Constant) & 15.711 & 3.577 & & 4.392 & .000 \\
\hline & Product Quality & .620 & .089 & .604 & 6.980 & .000 \\
\hline
\end{tabular}

a. Dependent Variable : Purchasing Decision

Source: Primary data from SPSS version 22 (2018)

Based on the simple linear regression calculation results in table 4.9 above, the regression equation is obtained:

$$
\mathrm{Y}=15.711+0,620 \mathrm{X}
$$

\section{Analisis Koefisien Korelasi}

Analysis of the interaction coefficient to determine the level of relationship between variables. The results of processing data with SPSS version 22 are as follows:

Table 2

Results of Product Moment Correlation Coefficient Data Processing

\section{Model Summary}

\begin{tabular}{ccccc}
\hline Model & & Adjusted $R$ & Std. Error \\
& $R$ & $R$ Square & Square & of the Estimate \\
\hline
\end{tabular}




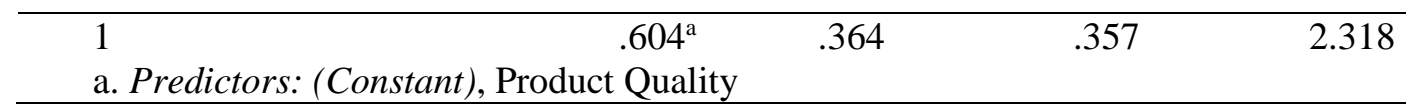

Source: Primary data from SPSS version 22 (2018)

Based on the calculation results in table 4.10 above, the correlation coefficient (r) of 0.604 is obtained. This means that product quality variables have a strong relationship to purchasing decisions according to the interpretation of correlation coefficient guidelines in table 4.11. So to find out how much influence the quality of the product on purchasing decisions using the coefficient of determination.

\section{Analisis Koefisien Determinasi}

Analysis of the coefficient of determination is intended to determine the percentage strength of the relationship between variables. Determination can be calculated using the formula: $\mathrm{KD}=\mathrm{R} 2 \times 100 \%$. The following is the calculation of the coefficient of determination processed by the SPSS version 22 program, seen in the table below:

Table 3

Results of Determination Coefficient Data Processing (KD)

Model Summary

\begin{tabular}{|c|c|c|c|c|}
\hline Model & $R$ & $\begin{array}{r}R \\
\text { Square }\end{array}$ & $\begin{array}{l}\text { Adjusted } R \\
\text { Square }\end{array}$ & $\begin{array}{l}\text { Std. Error } \\
\text { of the Estimate }\end{array}$ \\
\hline 1 & $.604^{a}$ & .364 & .357 & 2.318 \\
\hline
\end{tabular}

a. Predictors: (Constant), Product Quality

Source: Primary data from SPSS version 22 (2018)

Based on the calculation results in table 4.12 above, the coefficient of determination obtained 0.364 , it can be concluded that the quality of the product $(\mathrm{X})$ influences the purchase decision (Y) of $36.4 \%$ while the remaining $63.6 \%$ is influenced by other factors.

\section{Uji Hipotesis}

Table 4

Data Processing Results Hypothesis Testing / T-Test

\begin{tabular}{|c|c|c|c|c|c|c|}
\hline \multicolumn{7}{|c|}{ Coefficients ${ }^{a}$} \\
\hline \multirow[b]{2}{*}{ Model } & & \multicolumn{2}{|c|}{$\begin{array}{c}\text { Unstandardized } \\
\text { Coefficients }\end{array}$} & \multirow{2}{*}{$\begin{array}{c}\text { Standardized } \\
\text { Coefficients } \\
\text { Beta }\end{array}$} & \multirow[b]{2}{*}{$\mathrm{T}$} & \multirow[b]{2}{*}{ Sig. } \\
\hline & & B & $\begin{array}{c}\text { Std. } \\
\text { Error }\end{array}$ & & & \\
\hline 1 & (Constant) & 15.711 & 3.577 & & 4.392 & .000 \\
\hline & Kualitas Produk & .620 & .089 & .604 & 6.980 & .000 \\
\hline
\end{tabular}

Source: Primary data from SPSS version 22 (2018)

Based on the calculation in Table 4 above, the value of tcount $>t$ table or $(6.980>1.9883)$ is also strengthened with a significance value of $0,000<0.05$, so it can be said to be significant. This means that Ho is rejected and $\mathrm{H} 1$ is accepted, meaning there is a positive and significant 
influence between product quality on the purchase decision of Honda motorized scooters of automatic scooters

Figure 1.

Criteria for Determining Hypothesis Acceptance

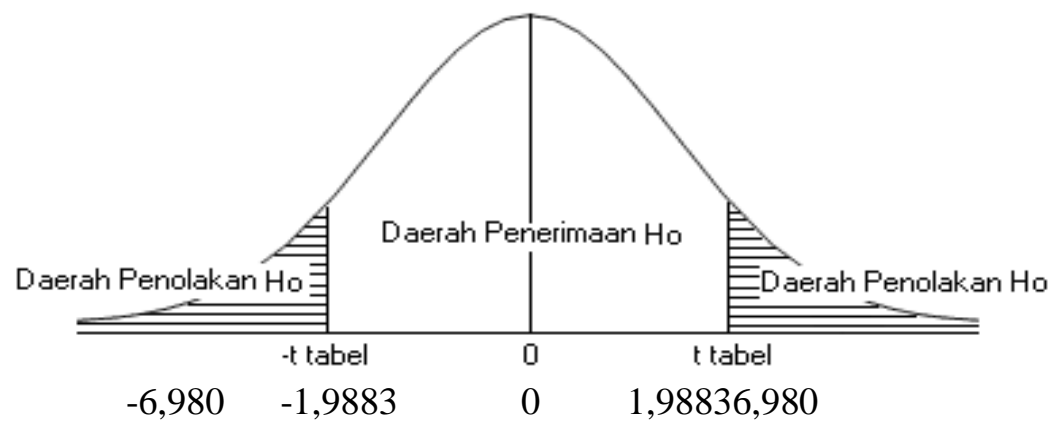

\section{CONCLUSION}

There is a strong and significant positive effect between product quality on purchasing decisions with a regression value of 0.620 . The correlation coefficient (r) of 0.604 and the value of determination $(\mathrm{Kd})$ of 0.364 or $36.4 \%$ while the remaining $63.6 \%$ is influenced by other factors. Hypothesis testing using statistical tests $t$ arithmetic obtained $t_{\text {count }}>t_{\text {table }}(6.980>$ 1.9883), this is also strengthened with a significance value of $0,000<0.05$, it can be said to be significant. Thus $\mathrm{H} 0$ is rejected and $\mathrm{H} 1$ is accepted, meaning there is a positive and significant influence between Product Quality on Purchasing Decisions.

\section{REFERENCES}

Amalia, D. (2015). Pengaruh Kualitas Pelayanan terhadap Loyalitas Pelanggan di Rental Mobil CV. Ilham Motor Gandu Mlarak Ponorogo. Al Tijarah. https://doi.org/10.21111/tijarah.v1i1.384

Anastasia, U \& Yulia, N. (2014). Pengaruh Kualitas Produk dan Citra Merek. Jurnal Ilmu dan Riset Manajemen.

Aryani, D., \& Rosinta, F. (2010). Pengaruh Kualitas Layanan terhadap Kepuasan Pelanggan dalam Membentuk Loyalitas Pelanggan. Jurnal Ilmu Administrasi dan Organisasi. 
Eriza, Z. N. (2017). Peran Mediasi Citra Merek dan Persepsi Risiko pada Hubungan antara Electronic Word of Mouth (E-WOM) dan Minat Beli (Studi pada Konsumen Kosmetik ECommerce di Solo Raya). Komuniti: Jurnal Komunikasi dan Teknologi Informasi. https://doi.org/10.23917/komuniti.v9i1.3501

Fatmawati, N., \& Soliha, E. (2017). Kualitas Produk, Citra Merek dan Persepsi Harga Terhadap Proses Keputusan Pembelian Konsumen Sepeda Motor Matic "Honda." Jurnal Manajemen Teori dan Terapan | Journal of Theory and Applied Management. https://doi.org/10.20473/jmtt.v10i1.5134

Fristiana, D. A. (2012). Pengaruh Citra Merek dan Harga Terhadap Keputusan Pembelian Pada Ramai Swalayan Peterongan Semarang. Ilmu Administrasi Bisnis.

Haromain, I. (2016). Pengaruh Layanan, Harga, Dan Lokasi Terhadap Kepuasan Pelanggan di AHASS Z618. Jurnal Ilmu dan Riset Manajemen.

Hidayati, T. A., Suharyono, \& Fanani, D. (2013). Pengaruh Citra Merek Terhadap Minat Beli dan Keputusan Pembelian Konsumen. Jurnal Administrasi Bisnis (JAB).

Isnaini Nur, Susanto, H. R. (2017). Pengaruh kualitas produk dan harga terhadap keputusan pembelian produk kosmetik Wardah. Jurnal Ekonomi \& Bisnis.

Istiatin, E. (2015). Pengaruh Kualitas Pelayanan Terhadap Kepuasan Konsumen Pada Dealer Pt. Ramayana Motor Sukoharjo. Jurnal Paradigma Universitas Islam Batik Surakarta.

Kurniasih, I. D. (2012). Pengaruh Harga Dan Kualitas Pelayanan Terhadap Loyalitas Pelanggan Melalui Variabel Kepuasan (Studi Pada Bengkel Ahass 0002-Astra Motor Siliwangi Semarang). Jurnal Administrasi Bisnis. https://doi.org/10.14710/jab.v1i1.4316

Kurniawati, D., \& Arifin, N. (2015). Strategi Pemasaran Melalui Media Sosial dan Minat Beli Mahasiswa. Jurnal Manajemen.

Loindong, S. S., \& Soegoto, A. S. (2014). Pengaruh Kualitas Produk, Harga Dan Lokasi Terhadap Kepuasan Konsumen Pada Warung-Warung Makan Lamongan Di Kota Manado. Jurnal Riset Ekonomi, Manajemen, Bisnis dan Akuntansi.

Munadi, F. A., Ekonomi, F., \& Gunadarma, U. (2008). Analisis Strategi Pemasaran untuk Meningkatkan Penjualan Kendaraan Motor pada CV Turangga Mas Motor. Journal of Economics.

Nurbaity L, A. (2004). Strategi Pemasaran dalam Persaingan Bisnis. Universitas Sumatra Utara.

Nuriyanti, W. (2017). Segmentasi Pasar Berdasarkan Demografi Dalam Memilih Sepeda Motor Matic Di Wilayah Depok. UTILITY: Jurnal Ilmiah Pendidikan dan Ekonomi.

Pahlevi, A. S., \& Sutopo. (2017). Pembelian Sepeda Motor Matik ( Studi Pada Yamaha Mataram Sakti Semarang ). Jurnal of Management.

Peter, J. P., \& Olson, J. C. (2014). Perilaku Konsumen dan Strategi Pemasaran. In salemba empat.

Schiffman, L., \& Kanuk, L. L. (2008). Perilaku konsumen. Jakarta: Indeks. 
Soegoto, A. S., Mandey, S., \& Sari, R. L. (2014). Citra Merek, Harga Dan Promosi Pengaruhnya Terhadap Keputusan Pembelian Perhiasan Emas Pada Pt. Pegadaian (Persero) Cabang Manado Utara. Jurnal Riset Ekonomi, Manajemen, Bisnis dan Akuntansi.

Sumarwan, U. (2014). Model Keputusan Konsumen. Perilaku konsumen.

Suryonaningsih, E. (2016). Effect of Price and Image Brand on Consumer Satisfaction. Journal of Management.

Tahir, A. (2005). Angkutan Massal Sebagai Alternatif Mengatasi Persoalan Kemacetan Lalu Lintas Kota Surabaya. Jurnal SMARTek.

Tjahjaningsih, E. (2016). Pengaruh Citra Dan Promosi Terhadap Kepuasan Pelanggan Serta Dampaknya Terhadap Loyalitas Pelanggan (Studi Pada Pelanggan Supermarket Carrefour Di Semarang). Media Ekonomi dan Manajemen. https://doi.org/10.24856/mem.v28i2.207

Wibowo, D. H., Arifin, Z., \& Sunarti, . (2015). Analisis Strategi Pemasaran Untuk Meningkatkan Daya Saing UMKM (Studi pada Batik Diajeng Solo). Jurnal Administrasi Bisnis.

Widhiastuti, R., Priyadi, E., \& Akhmadali. (2013). Evaluasi Dan Analisis Kebutuhan Ruang Parkir Di Kampus Politeknik Negeri Pontianak. Jurnal Teknik Sipil UNTAN.

Zainuddin, D. (2018). Pengaruh Kualitas Produk dan Brand Image terhadap Minat Beli Motor Matik. Sosio e-kons. https://doi.org/10.30998/sosioekons.v10i3.2902 
Pinisi Discretion Review

Volume 1, Issue 2, March, 2018 Page. 81-88 